\title{
AN ANALYSIS OF THE ECONOMIC DETERMINANTS AND THE QUALITY OF THE INSTITUTIONAL FRAMEWORK AS FACTORS TO ATTRACT FOREIGN DIRECT INVESTMENT IN SOUTH- EASTERN EUROPE: THE CASE OF GREECE
}

\author{
Constantinos CHOROMIDES \\ Metropolitan College, Athens,Greece
}

\begin{abstract}
Foreign Direct Investment (FDI) is considered by researchers as a critical factor for economic growth and development since they have shown a positive relationship between FDI and economic growth. The recent economic crisis in the European Union (EU) has brought up again the discussion of the key drivers specific to the attraction of FDI In addition to strict economic factors the literature emphasizes the role of institutions in a country as determinants in attracting FDI inflows. An analysis of the role that the quality of institutions in attracting FDI has in Greece is attempted using an econometric model on institutional, regulatory, country specific and firm level data. For the purpose of giving a regional dimension in the analysis, and for attempting a comparison of the findings, the analysis focuses besides Greece, in two other Southeastern European countries (SEE) Bulgaria and Romania, being two new member states of the EU.
\end{abstract}

Key Words: foreign direct investment, Southeastern Europe, institutions, economic growth, Greece

\section{Introduction}

At the aftermath of the economic crisis far too much talk about FDI and the urgent need to create a favorable climate and appropriate policies in order to allow Greece to attract FDI has been made. FDI in addition to the transfer of capital includes other substantive "intangible" resources such as know-how, development of human capital, new production methods, and technology (Vitalis 2002, Altomonte and Guagliano 2003, Kinoshita and Lu 2006). These resources, in the context of models of endogenous growth, play an important role and contribute significantly to the economic growth and development of countries by creating, among others, economies of scale in production, efficient methods of production and diffusion of knowledge (Schoors and Van Der Tol 2002, Pike et al. 2006). Therefore, FDI is considered as an essential developmental factor by a number of researchers such as Borensztein et al. (1998), De Mello (1999), Liu et al. (2002), Shan (2002), and Kim and Seo (2003).

In empirical level most macroeconomic studies have found a positive and statistically significant relationship between FDI and economic growth (Findlay 1978, Blomström et al. 1992, De Gregorio 1992, Blomström et al. 1994, Bende-Nabende and Ford 1998, Sanchez-Robles 1998, Baldwin et al. 1999, Zhang 2001, Campos and Kinoshita 2003, Kim et al. 2003, Vu and Noy 2009, Johnson 2006). These findings contradict some previous studies which concluded that FDI supersede domestic investments and therefore has a negative impact on economic growth and development (Hymer 1960, Caves 1971).

Concerning the factors determining FDI, apart from the purely economic ones, there are studies which emphasize the role of institutions and political stability in a country to attract foreign investors. Several econometric studies concluded that sound institutions and lack of corruption can attract FDI (Wei 2000b, Globerman and Shapiro 2002, Stern 2003, Daude and 
Stein 2007). Previous studies had also indicated that a country's poor FDI attractiveness is due to bureaucracy, ineffective tax system, corruption, labor market structure, and macroeconomic conditions (Apergis and Katrakilidis 1998, Pantelidis and Nikolopoulos 2008, Bitzenis et al. 2009). A recent study in 2011 about the reasons for the reluctance of international investors across Greece conducted by the Boston Consulting Group, shows that the main problems of Greece are: the bureaucracy; the unstable legal status with the continuous changes in the tax system; the administrative procedures; and the administration of justice (Boston Consulting Group 2011).

The purpose of this paper is to empirically provide evidence as to whether and to what extent the quality of institutions and regulations affect FDI inflows in Greece, a member state of the European Union (EU) since 1981, and of the Eurozone, since 2002. In order to give a regional dimension in the analysis, and for making the results comparable, our analysis focuses besides Greece, on Bulgaria and Romania, two new member states of the EU. Both countries joined the EU in 2007. Although previous research (Globerman and Shapiro 2002, Bénassy-Quéré et al. 2007, Daude and Stein 2007) has analyzed the effects of institutional determinants on FDI by employing country-level data, in this research a set of institutional and governance variables developed by the Heritage Foundation is employed, using also firm level data.

The motivation for studying the importance of the quality of institutions and the effectiveness of regulations as determinants on FDI in SEE region is that only recently these factors have been studied as determinants of FDI in former transitional economies, and it would be interested to examine whether the findings apply to a mature economy like Greece as well (Kaditi 2013, Estrin and Uvalic 2013).

The paper is organized as follows. The first section presents an overview of the evolution of FDI and institutional quality in SEE. The second section provides an overview of the relevant literature of the importance of economic activity, political and legal systems, business environment, and institutions in attracting foreign investors in a country. In section three the econometric model is explained, along with the dependent as well as the explanatory variables, whereas the empirical results are presented in the fourth section; section five presents a summary and conclusions.

\section{Foreign Direct Invest and Institutional Development in SEE}

Since Bulgaria and Romania cut from communism a new geographical space for business activities emerged. Economic conditions have undergone radical changes reformulating the business relationships of these two countries with foreign companies. The significance of the SEE markets has gained increasing interest among scholars to understand the nature of this region and its new business opportunities (Veremis and Daianu 2001, Choromides 2003). In the attempt to set up market economies for the former transitional economies and being new members of the EU, much attention was devoted to measures such as macroeconomic stability, privatisation, price and trade liberalisation. It is evident that research in these fields is necessary in order to understand the structural changes. However, the lack of research in the role of institutions in the SEE countries as determinants in attracting FDI inflows reflects a more general neglect of these economies.

The strategic location of the SEE region in the European continent, the opening of local markets for trade and investment, the continuous efforts in promoting institutional reforms for deeper integration in the EU, the comparatively low level of labour costs are only but a few of the determinant facts that make SEE region attractive for international investors. This is illustrated by the acceleration of FDI (Fig. 1). However, companies operating in the region faced a distinct institutional framework, which predetermined the strategic opportunities for businesses. That has created challenges for foreign investors. As a result, the SEE region has 
witnessed a considerable rise in FDI flows during the period 1992 to 2008 . Bulgaria and Romania have become very attractive and in 2008 , the two economies received $\$ 23.8$ out of $\$ 41.2$ billion dollars, whereas the FDI flows for Greece amounted to $\$ 4.5$ billion dollars. After years of growth, all SEE economies experienced a deep recession as a result of the global financial crisis in 2008.

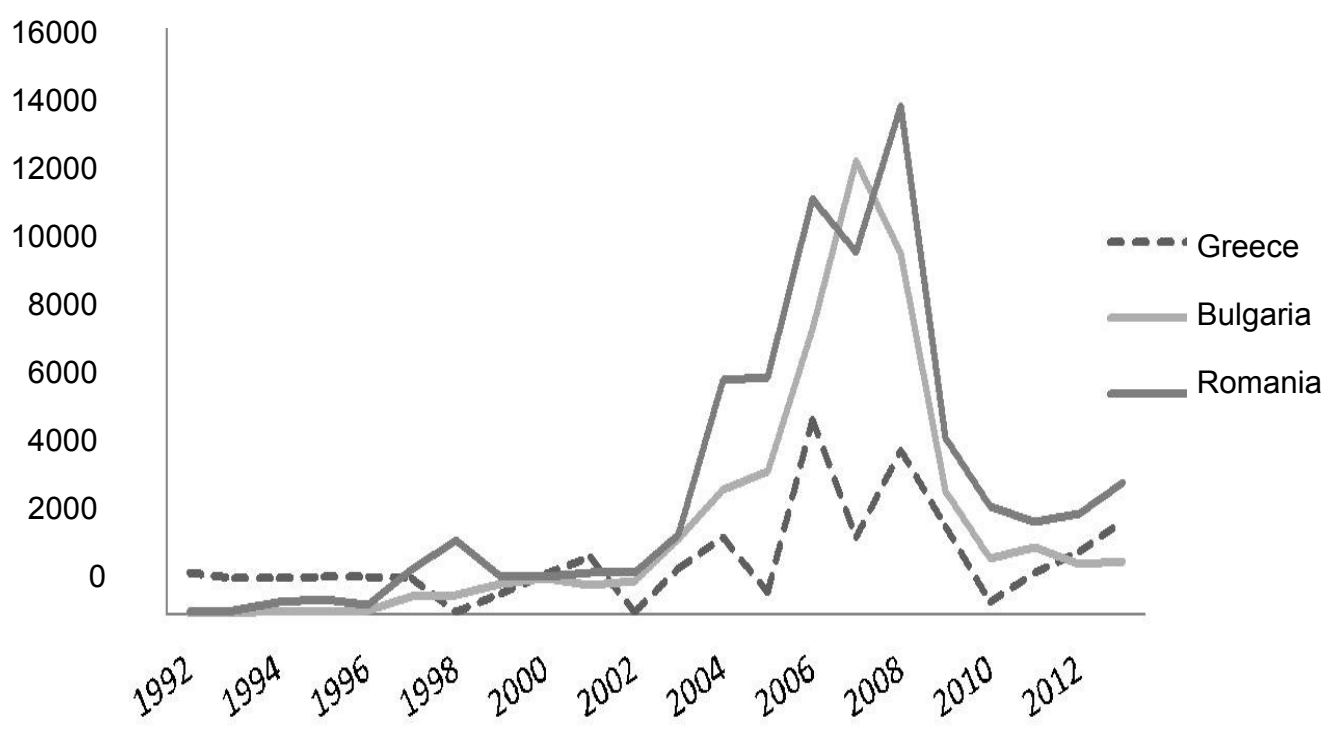

Fig. 1 - FDI inflows in Bulgaria, Greece, Romania (1992-2013) (Million \$) Source: UNCTAD statistics (processed by the author)

All the three SEE countries have made considerable progress in promoting private sector development via privatization, deregulation, and improving public administration, however, the unstable tax system, phenomena of corruption, lack of access to finance, restrictive labour policies and the poor quality of regulations are still perceived by foreign investors as the key constraints to invest in the region (Table 1).

Since 1995, the institutional and regulatory frameworks in the three SEE economies have been reformed at various extents. In the overall score on the Index of Economic Freedom 2014 developed by the Heritage Foundation, both Bulgaria and Romania rank better than Greece (Fig. 2). The index is graded on a scale of 0 to 100, with higher values indicating more rigid regulations. It is obvious that Bulgaria and Romania experienced significant improvements compared to Greece in most indicators over time, as higher values correspond to institutions and regulations of higher quality.

According to the Heritage Foundation's 2014 country report, Greece has achieved its highest level of economic freedom in 2010 , but its scores have dropped dramatically since then. Since 2010 , Greece's economic freedom has declined by 7.0 points, with scores falling in seven of the ten measured categories. The economic freedom score in 2014 is 55.7, making the Greek economy the $119^{\text {th }}$ freest in the 2014 Index. 


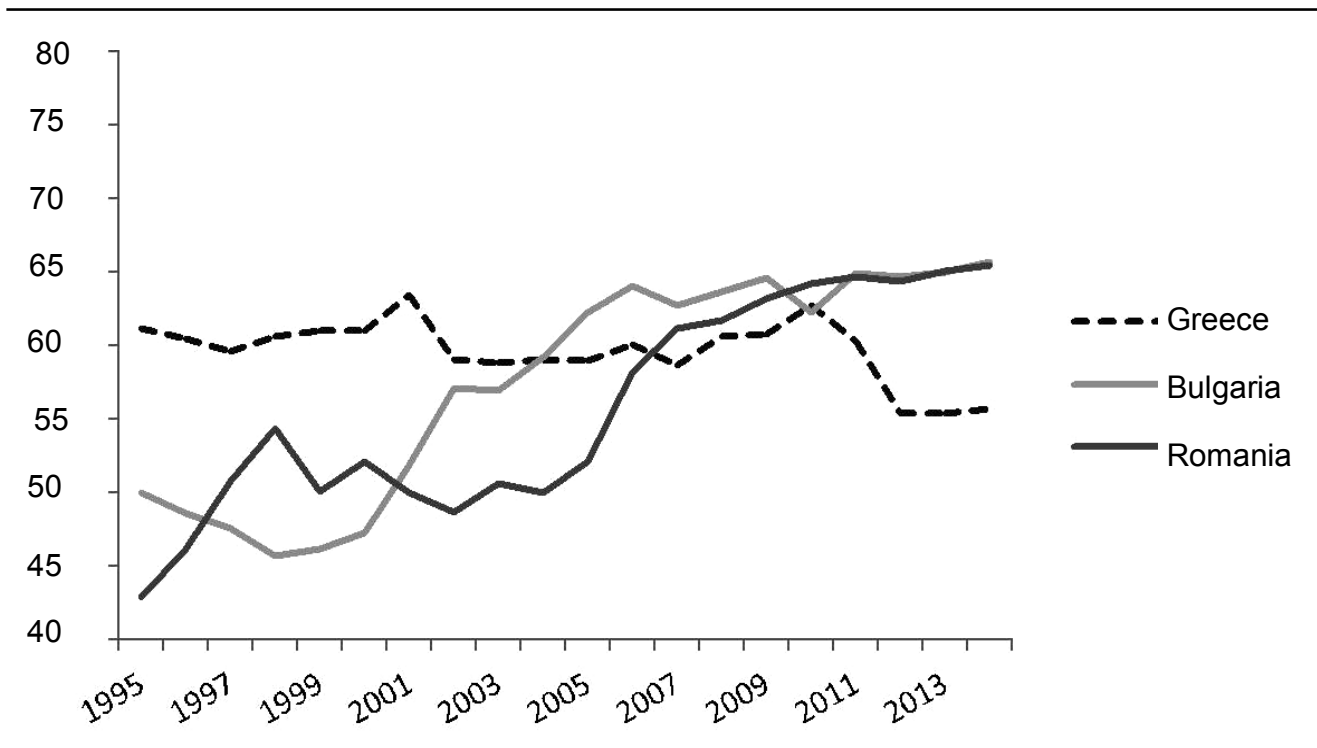

Fig. 2 - Index of Economic Freedom. Overall Score (1995-2014)

Source: Heritage Foundation, Index of Economic Freedom 2014 country reports (processed by the author)

Once considered as a "moderately free" economy, today Greece is considered as a "mostly unfree" economy. Greece is in the $40^{\text {th }}$ place out of 43 countries in the European region with its overall score below the world and regional averages. Throughout the history of the Index, Greece's economic freedom score has dropped by over 5 points (The Heritage Foundation, Index of Economic Freedom 2014). Although improvements in fiscal, business, labor, monetary, trade, and financial freedom, major declines in government spending, freedom from corruption, property rights, and last but not least investment freedom have cancelled out any gains. Despite efforts in the recent years to develop a more business friendly environment, the market conditions seem to be unable to amend the new economic realities, with tax evasion and corruption deeply-rooted in the economy.

Romania's economic freedom score is 65.5 , making its economy the $62^{\text {nd }}$ freest in the 2014 Index. Since 2010, Romania's economic freedom has increased by 1.3 points, with scores increasing in five of the ten categories, reflecting improvements in investment freedom, labor and monetary freedom, which advanced $5.0,4.8$ and 3.8 points respectively. Throughout the history of the Index, Romania's economic freedom score has increased by over 22 points. Romania is ranked $29^{\text {th }}$ out of 43 countries in the Europe region, and its overall score is higher than the world average (The Heritage Foundation, Index of Economic Freedom 2014). Despite, the remarkable economic performance in the recent years and its accession in the EU in 2007 , Romania's progression in terms of judicial independence and anti-corruption processes remain inefficient.

Bulgaria's economic freedom score is 65.7 , making its economy the $61^{\text {st }}$ freest in the 2014 Index. Since 2010, Bulgaria's economic freedom has increased by 3.4 points. Gains were recorded in six of the ten factors, led by management of government spending and monetary freedom, which advanced 16.2 and 10.1 points, respectively (The Heritage Foundation, Index of Economic Freedom 2014). Bulgaria is ranked $28^{\text {th }}$ out of 43 countries in the Europe region. Throughout the history of the Index, Bulgaria's economic freedom score has increased by over 
An Analysis of the Economic Determinants and the Quality of the Institutional Framework as Factors to Attract Foreign Direct Investment in Southeastern Europe: the Case of Greece

FDI and institutional indicators in SEE (1995-2014)

\begin{tabular}{|c|c|c|c|c|c|c|c|}
\hline $\begin{array}{l}\text { FDI Inflow } \\
\text { (in million } \\
\$ \text { \$) }\end{array}$ & Bulgaria & Greece & Romania & $\begin{array}{c}\text { Overall } \\
\text { Economic } \\
\text { Freedom } \\
\text { Score }\end{array}$ & Bulgaria & Greece & Romania \\
\hline 2013 & 1450 & 2567 & 3617 & 2014 & 65.7 & 55.7 & 65.5 \\
\hline 2010 & 1525 & 330 & 2940 & 2010 & 62.3 & 62.7 & 64.2 \\
\hline 2005 & 3920 & 623 & 6483 & 2005 & 62.3 & 59.0 & 52.1 \\
\hline 2000 & 1016 & 1108 & 1057 & 2000 & 47.3 & 61.0 & 52.1 \\
\hline 1995 & 90 & 1053 & 419 & 1995 & 50.0 & 61.2 & 42.9 \\
\hline $\begin{array}{l}\text { Property } \\
\text { Rights }\end{array}$ & & & & $\begin{array}{l}\text { Freedom } \\
\text { from cor- } \\
\text { ruption }\end{array}$ & & & \\
\hline 2014 & 30.0 & 40.0 & 40.0 & 2014 & 35.2 & 33.2 & 37.7 \\
\hline 2010 & 30.0 & 60.0 & 40.0 & 2010 & 36.0 & 47.0 & 38.0 \\
\hline 2005 & 30.0 & 50.0 & 30.0 & 2005 & 39.0 & 43.0 & 28.0 \\
\hline 2000 & 50.0 & 70.0 & 30.0 & 2000 & 29.0 & 49.0 & 30.0 \\
\hline 1995 & 50.0 & 70.0 & 30.0 & 1995 & 30.0 & 50.0 & 10.0 \\
\hline $\begin{array}{c}\text { Fiscal } \\
\text { Freedom }\end{array}$ & & & & $\begin{array}{c}\text { Govern- } \\
\text { ment } \\
\text { spending }\end{array}$ & & & \\
\hline 2014 & 91.2 & 65.9 & 65.9 & 2014 & 64.5 & 19.2 & 59.2 \\
\hline 2010 & 86.3 & 65.9 & 65.9 & 2010 & 48.3 & 41.9 & 59.8 \\
\hline 2005 & 80.3 & 58.0 & 58.0 & 2005 & 53.4 & 54.4 & 68.9 \\
\hline 2000 & 67.9 & 52.2 & 52.2 & 2000 & 54.4 & 54.4 & 63.3 \\
\hline 1995 & 46.0 & 62.5 & 62.5 & 1995 & 50.5 & 55.3 & 52.2 \\
\hline $\begin{array}{l}\text { Business } \\
\text { Freedom }\end{array}$ & & & & $\begin{array}{c}\text { Labor } \\
\text { Freedom }\end{array}$ & & & \\
\hline 2014 & 73.5 & 75.8 & 71.0 & 2014 & 80.2 & 53.9 & 65.2 \\
\hline 2010 & 77.8 & 77.4 & 72.5 & 2010 & 78.1 & 55.1 & 60.4 \\
\hline 2005 & 55.0 & 70.0 & 55.0 & 2005 & 80.3 & 56.1 & 55.5 \\
\hline 2000 & 55.0 & 70.0 & 55.0 & 2000 & $\mathrm{~N} / \mathrm{A}$ & $\mathrm{N} / \mathrm{A}$ & N/A \\
\hline 1995 & 55.0 & 70.0 & 55.0 & 1995 & $\mathrm{~N} / \mathrm{A}$ & $\mathrm{N} / \mathrm{A}$ & $\mathrm{N} / \mathrm{A}$ \\
\hline $\begin{array}{l}\text { Monetary } \\
\text { Freedom }\end{array}$ & & & & $\begin{array}{c}\text { Trade } \\
\text { Freedom }\end{array}$ & & & \\
\hline 2014 & 79.6 & 76.3 & 77.1 & 2014 & 87.8 & 82.8 & 87.8 \\
\hline 2010 & 69.5 & 77.6 & 73.3 & 2010 & 87.4 & 82.5 & 87.5 \\
\hline 2005 & 83.1 & 78.1 & 62.6 & 2005 & 82.0 & 80.2 & 70.4 \\
\hline 2000 & 0.0 & 75.5 & 38.1 & 2000 & 49.8 & 77.8 & 74.0 \\
\hline 1995 & 26.3 & 65.3 & 0.0 & 1995 & 72.4 & 77.8 & 79.0 \\
\hline $\begin{array}{c}\text { Invest- } \\
\text { ment } \\
\text { Freedom }\end{array}$ & & & & $\begin{array}{l}\text { Financial } \\
\text { Freedom }\end{array}$ & & & \\
\hline 2014 & 55.0 & 60.0 & 80.0 & 2014 & 60.0 & 50.0 & 50.0 \\
\hline 2010 & 50.0 & 60.0 & 75.0 & 2010 & 60.0 & 60.0 & 50.0 \\
\hline 2005 & 50.0 & 50.0 & 30.0 & 2005 & 70.0 & 50.0 & 50.0 \\
\hline 2000 & 70.0 & 70.0 & 70.0 & 2000 & 50.0 & 30.0 & 50.0 \\
\hline 1995 & 70.0 & 70.0 & 70.0 & 1995 & 50.0 & 30.0 & 50.0 \\
\hline
\end{tabular}

Source: The Heritage Foundation, Index of Economic Freedom 2014 
15 points, but further reform is necessary in order for Bulgaria to achieve a broad-based economic freedom and growth. In particular, institutional reforms must support judicial independence and tackle of corruption in order to strengthen the foundations of economic freedom and ensure progress toward greater prosperity.

\section{Literature Review and Empirical Studies}

According to Dunning (2000), the decision of foreign investors regarding the location of the investment is subject to the strategy they want to pursue. In the case where the strategic orientation of the foreign investors is resource seeking, the decision as to whether to invest depends on factor endowments differences, with foreign investors seeking to take advantage of either the natural resources or the cheap labor of the host country. If the strategic orientation of the foreign investors is market seeking investment or a market oriented strategy, the decision as whether to invest depends on the target country's domestic and regional market size, and market potential.

One of the strongest FDI determinants is the state of the economy. According to the literature the size of the domestic market and its growth potential are significant FDI determinants, suggesting that foreign investors seek to serve primarily the domestic market rather than the international market (Kobrin 1976, Nigh 1986, Shatz and Venables 2000, Torrisi et al. 2008). Billington (1999) and Fung et al. (2002) suggested that besides the absolute level of GDP which has a statistically significant positive impact on FDI inflows, the growth of an economy also has a statistically positive impact on the FDI flows in the host county. Al Nasser (2007) suggests that apart from the purely fundamental economic factors such as GDP growth and the size of the market, macroeconomic stability also affects the inflows of FDI. Similarly, Baniak et al. (2005) in their studying of the determinants of FDI inflows into transition countries suggested that macroeconomic stability increases FDI flows.

Another determinant factor that has a positive impact on the FDI inflows is the openness to trade, suggesting that in economies where tariff and non tariff barriers are not restrictive to trade also receive higher volumes of FDI inflows (Asiedu 2002, Addison and Heshmati 2003, Nonnenberg and Mendonça 2004, Bevan and Estrin 2004).

Apart from the purely economic factors, there are studies which emphasize the role of institutions and political stability in a country to attract foreign investors. Already by the end of the 1990s, emphasis was placed on the role of institutions as the basic parameters of economic growth (Acemoglu et al. 2005). The quality and the effectiveness of governmental institutions are seen as important factors in attracting FDI, since they affect the business and legal environments in a country (Blonigen 2005, Gani 2007) therefore good governance, a sound business environment are attractive location advantages for foreign investors (Singh and Jun 1995, Globerman and Shapiro 2003, Globerman et al. 2006, Busse and Hefeker 2007. Gani 2007, Busse and Groizard 2008, Dutta and Roy 2009, Barthel et al., 2010, Berger et al. 2011, 2013). Host countries with a sound business environment are able to attract more FDI (Dutta and Roy 2009) and reap the benefit of FDI and achieve economic growth more effectively (Busse and Groizard 2008).

According to the literature, capital market stability, sound and transparent regulations, legal stability and transparency positively affect FDI inflows, whereas political volatility significantly reduces inward FDI (Akhter 1993, Ramcharran 2000, Baniak et al. 2005, Bénassy-Quéré et al. 2007, Naudé and Krugell 2007, Bussmann 2010). Countries with a sound legal system are able to attract more inward FDI which contributes significantly to the economic growth and development (Baek and Qian 2011). In general, it is accepted that countries that record higher economic prosperity have greater political and economic freedom, better rights protection and intellectual property rights and lower level of corruption, thus perform relatively better in terms 
of FDI inflow (Acemoglu et al. 2005, Bénassy-Quéré et al. 2007). Buchanan et al. (2012) pointed out that the quality of institutions not only relates to the amount of FDI but also with their variability.

Wheeler and Mody (1992), Gani (2007), Groh and Wich (2009), suggest that complex and time consuming bureaucratic procedures affect the expected returns from investments, thereby negatively affect the decisions of foreign investors. Khan and Akbar (2013) employed several political risk indices such as government stability and corruption, while other studies have used corruption as a measure of political risk displaying a negative impact on FDI (Wheeler and Mody 1992, Wei 2000a, 2000b, Getz and Volkema 2001, Habib and Zurawicki 2002, BénassyQuéré et al. 2007). Similar factors also indicated by Wheeler and Mody (1992), Filippaios and Kottaridi (2013) who emphasize the particular influence exerted by the corruption. Finally, Bénassy-Quéré et al. (2007) find the impact of financial efficiency, the stability of the tax system, the efficiency of the judiciary and of supervisory instruments to be among those factors which exercise significant influence on FDI.

The institutions can have an impact on FDI through three channels. The first channel is through the direct impact that economic development has on FDI due to the positive macroeconomic prospects. Second because the low level of institutions involves an extra cost for foreign investors. In this case, for example, there are the costs incurred due to corruption (Wei 2000b). Third, because of the high non-recoverable costs, FDI is particularly prone to any form of instability. Especially with regard to greenfield investments, empirical evidence supports that they are influenced by the uncertainty arising from the political volatility, the effectiveness of the legal system and the extent to which the laws on property rights are enforced, given that this type of FDI require high irreversible costs (Stern 2003).

\section{Methodological Approach}

According to Dunning's OLI paradigm (1993), a firm must fulfill three criteria prior to any form of FDI. First the firm must possess certain ownership advantages that can balance the additional costs related with operating in a foreign market. The second condition of the OLI paradigm is that the firm must be in position to efficiently exploit in terms of cost of production its competitive advantages in a foreign rather than in the domestic market. The third criterion of international production is that it is more profitable for the company to transfer and exploit its ownership advantage across borders, than selling it to a third party via licensing or franchising.

The level of political and financial stability, quality and efficiency of regulatory and institutional factors, clearly affect the attractiveness of the location advantage of a given country, by diminishing the transaction costs foreign investors face. Therefore, countries with sound political and financial institutions are more attractive to foreign investors.

As a result, foreign investors are positively affected by favorable local market developments, either in terms of cost of production or market growth potential and the quality of institutions. In this context, following Kaditi (2013) the equation below will be used to explain FDI decisions in the three SEE Economies:

$$
\begin{aligned}
& \mathrm{FDI}_{i t}=a+b_{1} F \mathrm{Dl}_{i t-1}+b_{2} \text { Years }_{i t}+b_{3} \text { Resources }_{i t}+b_{4} \text { Firm Variables (Other) }_{i t-1}+ \\
& b_{5} \text { Institutional Variables }{ }_{i t-1}+b_{6} \text { Country Variables }{ }_{t}+b_{t} d_{t}+c_{i}+u_{i t}
\end{aligned}
$$

where $i$ indicates the $i^{\text {th }}$ firm, and $t$ indicates the time. The disturbance term is specified as a two -way error component model, so that firm heterogeneity is indicated by $c_{i}$, namely the unobserved firm-specific effect, whereas year-specific dummies, $d_{t}$, are included to account for common trends in the volume of FDI stock of the firms. $a, b$ are parameters to be estimated (Kaditi 2013). 
A detailed description of the variables used in the equation is presented in table 2.

The firm-level data used is retrieved from three commercial databases, ICAP, STAT BANK, and Amadeus. After deleting firms with incomplete and missing data, an unbalanced panel data was constructed which included 360 companies that have received FDI between 1996 and 2012, of which 157 are located in Greece, 95 are located in Bulgaria and 108 are located in Romania. Foreign investors are originated from all over the world, while we did not control for the sectoral distribution of the local firms. Regarding firm characteristics, twelve variables are employed and they are presented in detail in table 2 . More specifically we include specific firm variables to capture the effects of possible location advantages according to Dunning's (1993) OLI paradigm.

To estimate the possible effect of the firm's Size, the total capitalization of the firm is employed and it is expected to be positively related to FDI, since larger firms may receive larger flows of inward FDI. The firms' operating years (Years) is also included since established firms are expected to be more experienced to operate in the domestic market, therefore, diminishing the possible transaction cost of foreign investors, and they are expected to be more attractive to foreign investors. The Operating Profit of the firms may affect foreign investors' decision, since profitable firms are expected to be more attractive to foreign investors.

To examine possible location advantages, the firms' Operating Costs may be another factor important to foreign investors. Firms with higher operating costs (such as cost of material used, and labor costs) are expected to be less attractive to foreign investors therefore this exploratory variable is expected to be negatively related to the dependent variable. To examine the possible effect on the firm's ownership advantages, the explanatory variable $R \& D$ intensity is employed. Since a firm can develop new competitive technology using its own investments for $\mathrm{R} \& \mathrm{D}$, the explanatory variable is expected to be positively related to the investment decision of foreign investors.

It seems plausible that access to the best resources is already in the hands of local firms, and that the best way to access these resources is to invest in the target firm that holds them. For foreign investors the need for complementary inputs may be dominating over considerations concerning post-investment costs or risks. To examine the effect of the variable associated with resources' intensity, an explanatory variable Resources is employed, and it is expected to be positively related to the dependent variable.

While popular debate is often focusing on production costs, the attraction of markets is at least as important. Foreign firms facing constraints to growth within their domestic market are forced to explore new opportunities. If markets are saturated or rising costs reduce competitiveness, this creates strong motives for restructuring and relocation, searching for markets with growth potential, or use the new markets as export platforms from which to satisfy other neighboring foreign markets. Such a strategy is likely to include high start-up costs thus demand more dynamic followers. To examine this effect, an explanatory variable Growth Rate is employed. The higher the growth rate of sales of the target firms, the higher the amount of FDI is likely to be, therefore, a positive sign is expected for this explanatory variable.

Similarly, capital intensive companies require a large resource commitment but may yield large profits. Although high profits may induce companies not to invest in countries facing high financial risks this may be particular relevant if the company cannot afford the entire investment and it sees the partnership option as a way to complement its resources. To examine this effect, an explanatory variable Investment is employed and a positive sign is expected for this explanatory variable.

Financial resources are a firm's competitive advantage in the presence of asymmetric 
information regarding investments. Therefore, a firm with internal funds or low leverage is more likely to be attractive to foreign investors while a firm that needs to raise funds or face credit constraints may not be as attractive. Therefore, an explanatory variable measuring the share of debts over the firm's total assets, Total Debt, is employed.

Taxation is another explanatory variable that is expected to be negatively related to the dependent variable, since the lower the amount of net profit, the lower the amount of FDI inflows will be.

The contribution of exports over the sales of the firm is taken into consideration by employing the explanatory variable Exports, since international companies have competitive advantages that arise from their international activities as such. This includes international accumulation of know-how, arbitrage opportunities, flexibility for production shifting, superior recognition of opportunities, and international diversification of risk. With increasing presence in foreign markets and accumulated knowledge of these markets, the firm is in position to analyze the business environment more accurately and take estimated risks. Therefore, the firm becomes more competitive and confident in committing resources in foreign markets therefore this factor is expected to be positively related to the dependent variable.

An explanatory variable indicating the geographic diversification of companies, Geography, is employed, since companies with international experiences are expected to know better how to take advantage of new opportunities in a new foreign market, to face lower entry costs since they can exploit synergies within their international network, resulting in increasing value of their operations by serving more countries. Internationally experienced companies can use their market specific skills developed in foreign countries to overcome any market specific externalities against local competitors therefore this explanatory variable is expected to be positively related to the dependent variable.

Regarding the country control variables that may affect FDI, GDP and GDP per capita are two of the basic macroeconomic indicators of a country's economic performance reflecting the economic cycle of the economy; whether it is headed for growth or recession, and the consumption potential of the population in the domestic market. A growing economy and a higher consumption prospects are expected to positively affect the investment decision of market orientated investors to undertake FDI.

Another macroeconomic indicator that is employed and is expected to influence the decision of foreign investors is Inflation. High inflation rates minimize the consumption potential of the population in the domestic country, raise the price of production inputs and it is therefore expected to negatively affect any foreign investment decision.

Since economies with low tariff and non tariff barriers that impede international trade offer a solid foundation for international business activity, the explanatory variable Trade Openness indicating the country's open market orientation that may affect FDI decisions is employed.

The quality of institutions and regulations in the three SEE economies is expected to affect the investment decision of foreign investors. Overall, weak institutions are assumed to negatively affect investment decisions, while high quality institutions are expected to positively affect investment decisions. In order to examine the role that the quality of regulations and institutions has as determinants in attracting FDI, a group of explanatory variables is employed. The Index of Economic Freedom from the Heritage Foundation is an indicator which is calculated for 186 countries and it takes into account 50 independent variables, which are broken down into ten different categories. Their operational definitions are presented in detail in Table 2. Since higher values of these variables correspond to institutions and regulations of higher quality, the estimated coefficients are expected to be positive so that the economy is more attractive to investors 
Definitions of variables

\begin{tabular}{|c|c|c|c|}
\hline \multicolumn{2}{|r|}{ Institutional Variables } & \multirow{2}{*}{$\begin{array}{c}\text { Un } \\
\text { it } \\
{[\#]}\end{array}$} & Source \\
\hline \multirow[t]{2}{*}{$\begin{array}{l}\text { Rule } \\
\text { of law }\end{array}$} & $\begin{array}{l}\text { Property Rights: measures the degree to which a } \\
\text { country's laws protect private property rights and the } \\
\text { degree to which its government enforces those laws. It } \\
\text { also analyzes the independence of the judiciary, the } \\
\text { existence of corruption within the judiciary, and the ability } \\
\text { of individuals and businesses to enforce contracts. }\end{array}$ & & \multirow{10}{*}{$\begin{array}{l}\text { The } \\
\text { Heritage } \\
\text { Foundation } \\
\text { (Index of } \\
\text { Economic } \\
\text { Freedom) }\end{array}$} \\
\hline & $\begin{array}{l}\text { Freedom from Corruption: Corruption erodes economic } \\
\text { freedom by introducing insecurity and uncertainty into } \\
\text { economic relationships. }\end{array}$ & {$[\#]$} & \\
\hline \multirow[t]{2}{*}{$\begin{array}{l}\text { Govern- } \\
\text { ment } \\
\text { Size }\end{array}$} & $\begin{array}{l}\text { Fiscal Freedom measures the tax burden imposed by the } \\
\text { government. It includes both the direct tax burden in } \\
\text { terms of the top tax rates on individual and corporate } \\
\text { incomes and the overall amount of tax revenue as a } \\
\text { percentage of GDP. }\end{array}$ & {$[\#]$} & \\
\hline & $\begin{array}{l}\text { Government Spending measures the level of government } \\
\text { expenditures as a percentage of GDP. Government } \\
\text { expenditures, including consumption and transfers, } \\
\text { account for the entire score. }\end{array}$ & {$[\#]$} & \\
\hline \multirow{3}{*}{$\begin{array}{l}\text { Regula- } \\
\text { tory } \\
\text { Efficiency }\end{array}$} & $\begin{array}{l}\text { Business Freedom is a quantitative measure of the ability } \\
\text { to start, operate, and close a business. }\end{array}$ & {$[\#]$} & \\
\hline & $\begin{array}{l}\text { Labor Freedom is a quantitative measure that looks into } \\
\text { various aspects of the legal and regulatory framework of } \\
\text { a country's labor market. }\end{array}$ & {$[\#]$} & \\
\hline & $\begin{array}{l}\text { Monetary Freedom combines a measure of price stability } \\
\text { with an assessment of price controls. Both inflation and } \\
\text { price controls distort market activity. Price stability with- } \\
\text { out microeconomic intervention is the ideal state for the } \\
\text { free market. }\end{array}$ & {$[\#]$} & \\
\hline \multirow[t]{3}{*}{$\begin{array}{l}\text { Open } \\
\text { Markets }\end{array}$} & $\begin{array}{l}\text { Trade Freedom is a measure of the absence of tariff and } \\
\text { non-tariff barriers that affect imports and exports of goods } \\
\text { and } \quad \text { services. }\end{array}$ & {$[\#]$} & \\
\hline & $\begin{array}{l}\text { Investment Freedom measures the constraints on the } \\
\text { flow of investment capital. }\end{array}$ & {$[\#]$} & \\
\hline & $\begin{array}{l}\text { Financial Freedom is a measure of banking efficiency as } \\
\text { well as a measure of independence from government } \\
\text { control and interference in the financial sector. }\end{array}$ & {$[\#]$} & \\
\hline
\end{tabular}


An Analysis of the Economic Determinants and the Quality of the Institutional Framework as Factors to Attract Foreign Direct Investment in Southeastern Europe: the Case of Greece

\section{Definitions of variables}

\begin{tabular}{|c|c|c|c|}
\hline \multicolumn{2}{|r|}{ Firm Characteristics } & \multirow[b]{2}{*}{$\begin{array}{c}{[\%} \\
\text { of } \\
\text { rate }]\end{array}$} & \multirow{14}{*}{$\begin{array}{l}\text { ICAP, } \\
\text { STAT } \\
\text { BANK, } \\
\text { AMADEUS }\end{array}$} \\
\hline FDI & $\begin{array}{l}\text { The percentage of equity share owned by the foreign } \\
\text { firm. A firm is considered as foreign owned if foreign } \\
\text { invested capital is at least } 10 \% \text {. Since there is no data } \\
\text { available to indicate the change on foreign ownership } \\
\text { over time we assume that the percentage of foreign } \\
\text { equity share remains the same (Damijan et al. 2003). }\end{array}$ & & \\
\hline Size & Total capitalization of the company (measured in $€$ ). & {$[\#]$} & \\
\hline Resources & $\begin{array}{l}\text { The resource intensity is measured by a dummy varia- } \\
\text { ble, equal to } 1 \text { if the main economic activity of the com- } \\
\text { pany is in a resource-intensive industry and } 0 \text { other- } \\
\text { wise. }\end{array}$ & [\#] & \\
\hline Investment & $\begin{array}{l}\text { Capital intensity is proxied by the ratio of total assets/ } \\
\text { sales. }\end{array}$ & {$[\#]$} & \\
\hline Exports & Value of exports/sales of the company. & [\#] & \\
\hline Geography & $\begin{array}{l}\text { Number of different geographical markets in which the } \\
\text { company is active. }\end{array}$ & [\#] & \\
\hline Years & Number of years the firm operates. & {$[\#]$} & \\
\hline $\begin{array}{l}\text { Operating } \\
\text { Profit }\end{array}$ & Profit or loss after taxes. & [\#] & \\
\hline $\begin{array}{l}\text { Growth } \\
\text { Rate }\end{array}$ & $\begin{array}{l}\text { Percentage change of sales in the year of the invest- } \\
\text { ment over the following years. }\end{array}$ & $\begin{array}{l}{[\%} \\
\text { rate }]\end{array}$ & \\
\hline $\begin{array}{l}\text { Operating } \\
\text { Costs }\end{array}$ & The cost of labor and material inputs. & {$[\#]$} & \\
\hline R\&D & $\begin{array}{l}\text { Technological intensity is proxied by the percentage } \\
\text { ratio of R\&D expenditures over total sales. }\end{array}$ & $\begin{array}{l}{[\%} \\
\text { rate }]\end{array}$ & \\
\hline Total Debt & $\begin{array}{l}\text { The share of the total debt in terms of the firm's total } \\
\text { assets. }\end{array}$ & $\begin{array}{l}{[\%} \\
\text { rate }]\end{array}$ & \\
\hline Taxation & Percentage of the taxes paid in terms of a firm's sales. & $\begin{array}{l}{[\%} \\
\text { rate }]\end{array}$ & \\
\hline \multicolumn{3}{|c|}{ Country Variables } & \multirow{5}{*}{$\begin{array}{l}\text { UNCTAD } \\
\text { Statistics, } \\
\text { Bank of } \\
\text { Greece }\end{array}$} \\
\hline $\begin{array}{l}\text { GDP } \\
\text { per capita }\end{array}$ & The annual percentage change of GDP per capita. & $\begin{array}{l}{[\%} \\
\text { rate }]\end{array}$ & \\
\hline GDP & The annual percentage change rate of GDP. & $\begin{array}{l}0 \\
{[\%} \\
\text { rate }]\end{array}$ & \\
\hline $\begin{array}{l}\text { Trade } \\
\text { Openness }\end{array}$ & $\begin{array}{l}\text { The total volume of exports and imports as a share of } \\
\text { GDP. }\end{array}$ & $\begin{array}{l}\% \\
\text { rate }]\end{array}$ & \\
\hline Inflation & $\begin{array}{l}\text { The annual percentage change in the general level of } \\
\text { prices of products and services. }\end{array}$ & $\begin{array}{c}{[\%} \\
\text { rate }]\end{array}$ & \\
\hline
\end{tabular}

To control for any possible correlation problems since various institutional variables measure similar economic freedoms, we group those institutional variables that measure similar economic freedoms (Daude and Stein 2007). In particular, the average of Property Rights and Freedom from Corruption will be used in the equation as an indicator on Rule of Law, the average of Fiscal Freedom and Government Spending will be used in the equation as an indicator on Government Size, the average of Business Freedom, Labor Freedom and Monetary Freedom will be used in the equation as an indicator on Regulatory Efficiency, while the 
average of the remaining variables, Trade Freedom, Investment Freedom and Financial Freedom will be used in the equation as an indicator on Open Markets.

\section{Empirical Results}

Due to the nature and the use of the lagged predictive variable, and the statistical analysis of time series data, the linear least square estimators equation results not only to biased and inconsistent but to also to biased fixed and random effects estimators. To overcome this effect we employ a generalized method of moments procedure (Blundell and Bond 1998). The bias in the two step standard errors will be corrected by following the correction procedure of Windmeijer (2005). Following Arellano and Bond (1991) we are using an autocorrelation test, and in addition a Sargan test to examine over-identifying restrictions in our statistical model. The results suggest no serious problem. The Sargan test verifies the null hypotheses, that the over-identifying restrictions are valid. Similarly, the Arellano-Bond test reveals no significance effects of serial correlation in the first-differences errors. The results in Tables 3,4 and 5 suggest that the explanatory institutional and regulatory variables have a statistically significant relation to FDI in the three SEE economies. Regarding the importance of the coefficients, the results suggest that the effect of the institutional and regulatory quality on FDI is much higher for Greece than the 2 other SEE economies.

In columns 1 to 4 the four institutional and regulatory variables are reported separately. It is evident from the coefficients that the explanatory institutional variables for Greece, which are related to the Rule of Law and Regulatory Efficiency, are the explanatory variables with the highest estimators and with the highest statistical significance at less than $1 \%$ level, and appear to have a statistically significant negative effect on FDI. The existing literature (Wei 2000 b) supports our results that transactions costs incurred due to corruption that promotes uncertainty, and it raises transaction costs for foreign investors, thus their unfavorable development affects negatively FDI decision in Greece. The administrative procedures and the administration of justice are considerably deterring FDI decisions, since the results confirm that the quality of the institutions and regulations in Greece are factors which have been deteriorated and foreign investors consider them when choosing to expand their operation.

As far as the regulatory efficiency index is concerned, the results suggest that the lengthy and burdensome process for launching and operating a company had a statistically negative effect on FDI, indicating that one of the main problems of Greece is the bureaucracy. The legal framework consisting of lengthy and conflicting with unclear applicability procedures raise barriers to entry and, more importantly, suppress business. The resulting complexity creates a rigid and inefficient administration that impedes FDI (Lucas 1990, Singh and Jun 1995). Overall the results stress out that the business environment in Greece suffers not only from obstacles to operating a business, but also from the little protection offered to investors.

For Bulgaria, the importance of the coefficient which is related to the Rule of Law and the statistical significance at less than $5 \%$ level suggest that the impact on FDI, although negative, appears to be lower than in Greece. On the contrary, the importance of the coefficient which is related to the Regulatory Efficiency with statistical significance at less than $5 \%$ level appears to have a statistically significant positive effect on FDI. For Romania, the explanatory institutional variables which are related to the Rule of Law and Regulatory Efficiency, are the explanatory variables with the highest statistical significance at less than $1 \%$ level, and appear to have a statistically significant positive effect on FDI. Their evolution over time appear to have positively affected FDI in Romania.

The other indicators related to Government Size and Open Markets appear to play a less, still statistically significant negative role in affecting the decision of foreign investors in Greece. This result coincides with the findings of the existing literature (Ramcharran 2000, Baniak et al. 2005, Naudé and Krugell 2007). Although the government has changed the existing incentive 
An Analysis of the Economic Determinants and the Quality of the Institutional Framework as Factors to Attract Foreign Direct Investment in Southeastern Europe: the Case of Greece

\section{Empirical Results}

Table 3

\begin{tabular}{|c|c|c|c|c|}
\hline & $\begin{array}{c}\text { Rule of } \\
\text { law }\end{array}$ & $\begin{array}{c}\text { Government } \\
\text { Size } \\
\end{array}$ & Regulatory Efficiency & Open Markets \\
\hline \multirow[t]{2}{*}{ FDI Greece } & 0.637 & 0.754 & 0.584 & 0.564 \\
\hline & $(0.062)^{\star \star \star}$ & $(0.070)^{\star \star \star}$ & $(0.078)^{\star \star \star *}$ & $(0.072)^{\star \star \star}$ \\
\hline \multirow[t]{2}{*}{ Size } & 0.130 & 0.130 & 0.138 & 0.075 \\
\hline & $(0.075)^{*}$ & $(0.052)^{\star \star}$ & $(0.055)^{\star *}$ & $(0.052)^{*}$ \\
\hline \multirow[t]{2}{*}{ Resource } & 0.204 & 0.217 & 0.124 & 0.256 \\
\hline & $(0.054)^{\star \star \star}$ & $(0.050)^{\star \star \star}$ & $(0.073)^{*}$ & $(0.060)^{\star \star \star}$ \\
\hline \multirow[t]{2}{*}{ Investment } & 0.035 & 0.028 & 0.003 & 0.042 \\
\hline & $(0.015)^{* *}$ & $(0.017)^{*}$ & $(0.004)$ & $(0.020)^{* *}$ \\
\hline \multirow[t]{2}{*}{ Growth Rate } & 0.028 & 0.007 & 0.157 & 0.206 \\
\hline & $(0.017)^{*}$ & $(0.014)^{*}$ & $(0.096)^{\star *}$ & $(0.160)^{\star *}$ \\
\hline \multirow[t]{2}{*}{ Exports } & 0.201 & 0.068 & 0.080 & 0.048 \\
\hline & $(0.037)^{\star \star *}$ & $(0.042)^{*}$ & $(0.030)^{\star \star}$ & $(0.020)^{\star *}$ \\
\hline \multirow[t]{2}{*}{ Geography } & 0.184 & 0.150 & 0.068 & 0.152 \\
\hline & $(0.064)^{\star \star \star}$ & $(0.060)^{* \star}$ & $(0.067)$ & $(0.060)^{\star \star}$ \\
\hline \multirow[t]{2}{*}{ Years } & 0.548 & 0.380 & 0.769 & 0.148 \\
\hline & $(0.060)^{\star \star \star}$ & $(0.068)^{* * *}$ & $(0.072)^{\star \star \star}$ & $(0.062)^{\star *}$ \\
\hline \multirow{2}{*}{$\begin{array}{l}\text { Operating } \\
\text { Profit }\end{array}$} & 0.018 & 0.008 & 0.003 & 0.009 \\
\hline & $(0.051)$ & $(0.021)$ & $(0.006)$ & $(0.006)$ \\
\hline \multirow[t]{2}{*}{ R\&D } & 0.206 & 0.074 & 0.071 & 0.053 \\
\hline & $(0.024)^{\star \star \star}$ & $(0.026)^{\star \star \star}$ & $(0.044)^{*}$ & $(0.039)^{*}$ \\
\hline \multirow[t]{2}{*}{ Operating Costs } & 0.257 & 0.082 & 0.071 & 0.121 \\
\hline & $(0.364)$ & $(0.125)$ & $(0.140)$ & $(0.128)$ \\
\hline \multirow[t]{2}{*}{ Total Debt } & -0.293 & -0.263 & -0.364 & -0.185 \\
\hline & $(0.075)^{\star \star \star}$ & $(0.069)^{\star \star \star}$ & $(0.180)^{\star \star}$ & $(0.067)^{\star \star \star}$ \\
\hline \multirow[t]{2}{*}{ Taxation } & -0.086 & -0.075 & -0.017 & -0.023 \\
\hline & $(0.217)$ & $(0.135)$ & $(0.028)$ & $(0.026)$ \\
\hline \multirow[t]{2}{*}{ GDP per capita } & 1.077 & 0.797 & 1.093 & 0.311 \\
\hline & $(0.365)^{\star \star \star *}$ & $(0.219)^{\star \star \star}$ & $(0.358)^{\star \star \star}$ & $(0.153)^{\star *}$ \\
\hline \multirow[t]{2}{*}{ GDP } & 0.053 & 0.042 & 0.013 & 0.051 \\
\hline & $(0.009)^{\star \star \star *}$ & $(0.017)^{\star \star}$ & $(0.024)$ & $(0.009)^{\star * \star *}$ \\
\hline \multirow[t]{2}{*}{ Trade Openness } & 0.048 & 0.137 & 0.032 & 0.078 \\
\hline & $(0.682)$ & $(0.502)$ & $(0.518)$ & $(0.497)$ \\
\hline \multirow[t]{2}{*}{ Inflation } & -0.041 & -0.027 & -0.020 & -0.011 \\
\hline & $(0.008)^{\star \star \star}$ & $(0.007)^{\star \star \star}$ & $(0.007)^{\star \star \star}$ & $(0.005)^{\star \star}$ \\
\hline \multirow[t]{2}{*}{ Rule of Law } & -0.188 & & & \\
\hline & $(0.064)^{\star * \star}$ & & & \\
\hline \multirow[t]{2}{*}{ Government Size } & & -0.102 & & \\
\hline & & $(0.023)^{\star \star \star}$ & & \\
\hline
\end{tabular}


Empirical Results

Table 3

\begin{tabular}{|c|c|c|c|c|}
\hline & $\begin{array}{l}\text { Rule of } \\
\text { law }\end{array}$ & $\begin{array}{c}\text { Government } \\
\text { Size }\end{array}$ & Regulatory Efficiency & Open Markets \\
\hline $\begin{array}{l}\text { Regulatory } \\
\text { Efficiency }\end{array}$ & & & $\begin{array}{l}-0.174 \\
(0.121)^{\star \star \star}\end{array}$ & \\
\hline Open Markets & & & & $\frac{-0.065}{(0.035)^{*}}$ \\
\hline Constant & -1.483 & -1.850 & 1.272 & 1.812 \\
\hline & $(1.704)$ & $(1.395)$ & $(1.493)$ & $(1.104)$ \\
\hline Sargan test & 0.066 & 0.125 & 0.153 & 0.097 \\
\hline $\begin{array}{l}\text { Auto- } \\
\text { correlation test }\end{array}$ & 0.108 & 0.341 & 0.375 & 0.162 \\
\hline
\end{tabular}

Values in the parentheses are Standard Errors. No Obs: 2.512. The P-values are reported for the Sargan and the auto-correlation tests. Significance levels: $p<0.01^{* * *}, p<0.05^{* *}, p<0.1^{*}$.

policies, comprising the need to attract FDI, through significant fiscal and financial provisions, the unstable legal status, the fact that Greece's trade policies still favor domestic companies while the EU members have very low tariff rates and few non-tariff barriers, and the constant changes in the tax bill are considerably deterring FDI. The successive changes in the tax regime for example constitute a serious obstacle to any interested foreign investor. FDI are long-term investments which are not easily reversible. Hence, any investor should be able to assess the revenue and the cost of its investment long-term which implies that knows in advance the legal and tax obligations.

Greece's economy is moderately free, facing major fiscal weaknesses. The recent public debt and unemployment crises have not been adequately addressed and as a result there are significant delays in structural changes in particular as regards to the operation of the market and the difficulty to access finance. With economic uncertainty detering FDI, the overall stability of the financial system destabilized, Greece's attractiveness as an FDI location with regard to the Open Markets explanatory variables has to be improved. On the contrary, the explanatory institutional variables for Bulgaria and Romania, which are related to the Government Size and Open Markets, and are statistical significant at less than $5 \%$ level, appear to have a statistically significant positive effect on FDI. Their evolution over time, appear to positively contribute to the attraction of FDI in Bulgaria and Romania.

Contrary to the emphasis placed by the EU on the ability of the Eurozone countries to attract FDI, the results suggest that Greece failed on the implementation of structural reforms leading to a stable and working market economy, the development of appropriate and transparent commercial laws, the restructuring of the industrial base, all of which are factors that can lead to an increased volume of FDI, and therefore to swift integration to the Eurozone (Altomonte and Guagliano 2003). The combining effect of the ambiguous FDI policies and the weak economic environment in Greece discouraged the international investors, with direct restrictive result to the attraction of FDI inflows. To this end, there is a need for an enhanced effectiveness of competition policy through the introduction of a "centrally-led review of stock of laws and regulations for competitive effects with follow-up revisions of laws and regulations that unnecessarily restrain competition" (OECD 2014: 18).

The results indicate that an efficiently regulated economy, clearly defined laws, effective political and economic institutions, all of which are determinant factors of macroeconomic 
stability, capital market and private sector development, are expected to positively influence economic growth through the promotion of FDI (Ramcharran 2000, Altomonte 2000).

Regarding the firm-specific variables for Greece, the results are positive and statistically significant. Firms that have received foreign investments may, therefore, be more attractive in the future as well. Similarly, the results of the Size and R\&D variables are positive and statistical significant, indicating that foreign investors prefer large firms and those who can acquire new technology. Furthermore, the capital and resource intensity the growth rate of sales explanatory variables, and last but not least, the advantages related to the geographical diversification, and export orientation of the local firms, are positive and statistically significant.

The relevant positive and significant coefficients of the geographical diversification, and export orientation of the local firms suggest that foreign investors seek not only to serve the domestic market but the international market as well. This finding does not coincide with the findings of Kobrin (1976), Nigh (1986), Shatz and Venables (2000) and Torrisi et al. (2008) who suggested that foreign investors seek to serve primarily the domestic rather than the international market. As expected, Total Debt appears to negatively affect FDI, whereas the coefficient of Years indicates that established firms with experience are more attractive to investors.

Table 4

Empirical Results (cont.)

\begin{tabular}{|c|c|c|c|c|}
\hline & Rule of law & Government Size & Regulatory Efficiency & Open Markets \\
\hline \multirow[t]{2}{*}{ FDI Bulgaria } & 0.724 & 0.762 & 0.543 & 0.411 \\
\hline & $(0.337)^{\star \star}$ & $(0.335)^{* *}$ & $(0.277)^{\star \star}$ & $(0.168)^{* *}$ \\
\hline \multirow[t]{2}{*}{ Size } & 0.137 & 0.133 & 0.289 & 0.165 \\
\hline & $(0.052)^{\star *}$ & $(0.063)^{\star \star}$ & $(0.169)^{*}$ & $(0.088)^{*}$ \\
\hline \multirow[t]{2}{*}{ Resource } & 0.157 & 0.246 & 0.123 & 0.384 \\
\hline & $(0.068)^{* *}$ & $(0.070)^{\star \star \star}$ & $(0.055)^{* *}$ & $(0.100)^{\star \star \star}$ \\
\hline \multirow[t]{2}{*}{ Investment } & 0.007 & 0.015 & 0.041 & 0.010 \\
\hline & $(0.017)$ & $(0.002)^{\star * *}$ & $(0.005)^{\star * \star}$ & $(0.004)^{* *}$ \\
\hline \multirow[t]{2}{*}{ Growth Rate } & 0.007 & 0.002 & 0.40 & 0.01 \\
\hline & $(0.008)$ & $(0.003)$ & $(0.259)^{\star}$ & $(0.019)$ \\
\hline \multirow[t]{2}{*}{ Exports } & 0.083 & 0.098 & 0.065 & 0.047 \\
\hline & $(0.030)^{\star * *}$ & $(0.041)^{\star *}$ & $(0.023)^{\star * *}$ & $(0.026)^{\star}$ \\
\hline \multirow[t]{2}{*}{ Geography } & 0.188 & 0.167 & 0.143 & 0.175 \\
\hline & $(0.087)^{* *}$ & $(0.030)^{\star \star \star *}$ & $(0.020)^{\star \star \star}$ & $(0.020)^{\star \star \star}$ \\
\hline \multirow[t]{2}{*}{ Years } & 0.230 & 0.167 & 0.315 & 0.472 \\
\hline & $(0.086)^{* \star}$ & $(0.052)^{\star \star \star}$ & $(0.080)^{\star \star \star}$ & $(0.075)^{\star \star \star}$ \\
\hline \multirow{2}{*}{$\begin{array}{l}\text { Operating } \\
\text { Profit }\end{array}$} & 0.0024 & 0.074 & 0.030 & 0.021 \\
\hline & $(0.143)$ & $(0.055)$ & $(0.027)$ & $(0.168)$ \\
\hline \multirow[t]{2}{*}{ R\&D } & 0.015 & 0.009 & 0.007 & 0.004 \\
\hline & $(0.010)$ & $(0.020)$ & $(0.009)$ & $(0.010)$ \\
\hline \multirow{2}{*}{$\begin{array}{l}\text { Operating } \\
\text { Costs }\end{array}$} & 0.117 & 0.093 & 0.157 & 0.061 \\
\hline & $(0.024)^{* \star *}$ & $(0.018)^{\star \star \star}$ & $(0.064)^{\star *}$ & $(0.024)$ \\
\hline \multirow[t]{2}{*}{ Total Debt } & -0.312 & -0.254 & -0.179 & -0.440 \\
\hline & $(0.105)^{\star \star \star}$ & $(0.072)^{\star \star \star}$ & $(0.090)^{\star *}$ & $(0.109)^{\star \star \star}$ \\
\hline \multirow[t]{2}{*}{ Taxation } & -0.013 & -0.017 & -0.011 & -0.020 \\
\hline & $(0.017)$ & $(0.062)$ & $(0.025)$ & $(0.039)$ \\
\hline
\end{tabular}


Empirical Results (cont.)

\begin{tabular}{|c|c|c|c|c|}
\hline & Rule of law & Government Size & Regulatory Efficiency & Open Markets \\
\hline \multirow{2}{*}{$\begin{array}{l}\text { GDP } \\
\text { per capita }\end{array}$} & 0.567 & 0.839 & 0.338 & 0.452 \\
\hline & $(0.210)^{\star \star \star}$ & $(0.277)^{\star \star \star}$ & $(0.183)^{\star}$ & $(0.164)^{\star \star \star}$ \\
\hline \multirow{2}{*}{ GDP } & 0.016 & 0.020 & 0.018 & 0.007 \\
\hline & $(0.017)$ & $(0.010)^{\star *}$ & $(0.010)^{*}$ & $(0.009)$ \\
\hline \multirow{2}{*}{$\begin{array}{l}\text { Trade Open- } \\
\text { ness }\end{array}$} & 1.275 & 0.225 & 0.085 & 0.429 \\
\hline & $(1.204)^{\star \star}$ & $(1.611)$ & $(0.403)^{* *}$ & $(0.407)^{\star *}$ \\
\hline \multirow[t]{2}{*}{ Inflation } & -0.041 & -0.019 & -0.015 & -0.028 \\
\hline & $(0.010)^{\star \star \star}$ & $(0.008)^{\star \star}$ & $(0.004)^{\star \star *}$ & $(0.010)^{\star \star \star}$ \\
\hline \multirow[t]{2}{*}{ Rule of Law } & -0.028 & & & \\
\hline & $(0.012)^{* \star}$ & & & \\
\hline \multirow{2}{*}{$\begin{array}{l}\text { Government } \\
\text { Size }\end{array}$} & & 0.783 & & \\
\hline & & $(0.319)^{\star *}$ & & \\
\hline \multirow{2}{*}{$\begin{array}{l}\text { Regulatory } \\
\text { Efficiency }\end{array}$} & & & 0.495 & \\
\hline & & & $(0.080)^{\star \star}$ & \\
\hline $\begin{array}{l}\text { Open } \\
\text { Markets }\end{array}$ & & & & $\begin{array}{c}0.238 \\
(0.099)^{\star *}\end{array}$ \\
\hline \multirow[t]{2}{*}{ Constant } & 0.408 & -2.583 & 1.293 & 2.485 \\
\hline & $(2.561)$ & $(2.797)^{*}$ & $(1.706)$ & $(1.795)$ \\
\hline Sargan test & 0.057 & 0.155 & 0.067 & 0.084 \\
\hline $\begin{array}{l}\text { Auto- } \\
\text { correlation } \\
\text { test }\end{array}$ & 0.176 & 0.193 & 0.358 & 0.642 \\
\hline
\end{tabular}

Values in the parentheses are Standard Errors. No Obs: 1.520. The P-values are reported for the Sargan and the auto-correlation tests. Significance levels: $0.01^{* * *}, 0.05^{\star *}, 0.1^{*}$.

For Bulgaria and Romania, the results of Operating Costs suggest an efficiency seeking FDI form of investment by firms seeking lower operating costs by either relocating production facilities to countries with lower labour cost or outsourcing elements in the value chain to lower cost of suppliers abroad, a motivation cited in the literature for FDI in former transition economies (Estrin et al. 2000, Bevan and Estrin 2004), while the results of the R\&D variable, although positive, are not statistically significant. In comparison with Greece, FDI in Bulgaria and Romania is aiming mainly in traditional and low technology sectors.

The coefficients of the country-specific variables GDP and GDP per capita are positive and statistically significant for all countries, whereas Inflation has a negative impact on FDI flows. These results are consistent with the findings of Billington (1999), Fung et al. (2002), Baniak et al. (2005) and Al Nasser (2007), who conclude that macroeconomic stability and the growth potential of the economy are among the main determinants of FDI. The results indicate that FDI flows in SEE were also driven by the market size and consumer demand, therefore the orientation of the foreign firms that have invested in the region was market seeking, either investing in established local brands and, or local supply chain networks. The large inflows of FDI to SEE have often been argued to be explained in terms of firms seeking new or quickly growing markets for their products (Lankes and Venables 1996). 
An Analysis of the Economic Determinants and the Quality of the Institutional Framework as Factors to Attract Foreign Direct Investment in Southeastern Europe: the Case of Greece

\section{Empirical Results (cont.)}

\begin{tabular}{|c|c|c|c|c|}
\hline & Rule of law & Government Size & Regulatory Efficiency & Open Markets \\
\hline \multirow[t]{2}{*}{ FDI Romania } & 0.532 & 0.415 & 0.659 & 0.660 \\
\hline & $(0.295)^{*}$ & $(0.215)^{*}$ & $(0.386)^{*}$ & $(0.262)^{* *}$ \\
\hline \multirow[t]{2}{*}{ Size } & 0.169 & 0.188 & 0.169 & 0.175 \\
\hline & $(0.068)^{\star \star}$ & $(0.088)^{* *}$ & $(0.077)^{\star \star}$ & $(0.096)^{\star}$ \\
\hline \multirow[t]{2}{*}{ Resource } & 0.136 & 0.148 & 0.191 & 0.086 \\
\hline & $(0.068)^{* *}$ & $(0.070)^{\star \star *}$ & $(0.055)^{\star \star}$ & $(0.034)^{\star *}$ \\
\hline \multirow[t]{2}{*}{ Investment } & 0.066 & 0.041 & 0.007 & 0.065 \\
\hline & $(0.047)^{*}$ & $(0.022)^{*}$ & $(0.004)^{*}$ & $(0.021)^{\star \star \star}$ \\
\hline \multirow[t]{2}{*}{ Growth Rate } & 0.027 & 0.015 & 0.086 & 0.074 \\
\hline & $(0.009)^{\star * *}$ & $(0.009)^{\star}$ & $(0.047)^{*}$ & $(0.016)^{\star \star *}$ \\
\hline \multirow[t]{2}{*}{ Exports } & 0.057 & 0.070 & 0.054 & 0.080 \\
\hline & $(0.022)^{\star *}$ & $(0.033)^{*}$ & $(0.020)^{\star *}$ & $(0.073)^{*}$ \\
\hline \multirow[t]{2}{*}{ Geography } & 0.164 & 0.139 & 0.158 & 0.298 \\
\hline & $(0.066)^{\star *}$ & $(0.048)^{\star \star \star}$ & $(0.052)^{\star \star \star}$ & $(0.153)^{\star \star}$ \\
\hline \multirow[t]{2}{*}{ Years } & 0.195 & 0.115 & 0.244 & 0.376 \\
\hline & $(0.088)^{* *}$ & $(0.058)^{* *}$ & $(0.057)^{\star * *}$ & $(0.095)^{\star \star *}$ \\
\hline \multirow{2}{*}{$\begin{array}{l}\text { Operating } \\
\text { Profit }\end{array}$} & 0.015 & 0.009 & 0.021 & 0.016 \\
\hline & $(0.019)$ & $(0.012)$ & $(0.036)$ & $(0.095)$ \\
\hline \multirow[t]{2}{*}{ R\&D } & 0.148 & 0.058 & 0.063 & 0.009 \\
\hline & $(0.210)$ & $(0.115)$ & $(0.192)$ & $(0.014)$ \\
\hline \multirow{2}{*}{$\begin{array}{l}\text { Operating } \\
\text { Costs }\end{array}$} & 0.141 & 0.194 & 0.029 & 0.108 \\
\hline & $(0.039)^{\star * \star}$ & $(0.095)^{\star *}$ & $(0.032)$ & $(0.032)^{\star \star *}$ \\
\hline \multirow[t]{2}{*}{ Total Debt } & -0.196 & -0.157 & -0.168 & -0.235 \\
\hline & $(0.086)^{\star *}$ & $(0.054)^{\star \star \star *}$ & $(0.071)^{\star \star}$ & $(0.104)^{\star *}$ \\
\hline \multirow[t]{2}{*}{ Taxation } & -0.064 & -0.079 & -0.044 & -0.038 \\
\hline & $(0.182)$ & $(0.146)$ & $(0.158)$ & $(0.167)$ \\
\hline \multirow{2}{*}{$\begin{array}{l}\text { GDP per } \\
\text { capita }\end{array}$} & 0.376 & 0.472 & 0.298 & 0.275 \\
\hline & $(0.167)^{\star *}$ & $(0.145)^{\star \star \star *}$ & $(0.139)^{* *}$ & $(0.117)^{\star *}$ \\
\hline \multirow[t]{2}{*}{ GDP } & 0.108 & 0.167 & 0.119 & 0.086 \\
\hline & $(0.029)^{\star \star \star}$ & $(0.072)^{\star *}$ & $(0.093)^{*}$ & $(0.025)^{\star \star \star}$ \\
\hline \multirow{2}{*}{$\begin{array}{l}\text { Trade Open- } \\
\text { ness }\end{array}$} & 1.447 & 0.049 & 1.182 & 1.168 \\
\hline & $(0.394)^{\star \star \star}$ & $(0.348)$ & $(0.338)^{\star \star * *}$ & $(0.279)^{\star \star \star}$ \\
\hline \multirow[t]{2}{*}{ Inflation } & -0.025 & -0.033 & -0.085 & -0.067 \\
\hline & $(0.007)^{\star \star \star *}$ & $(0.011)^{\star \star *}$ & $(0.022)^{\star \star \star}$ & $(0.030)^{\star \star}$ \\
\hline Rule of Law & $\begin{array}{c}0.746 \\
(0.214)^{\star \star \star}\end{array}$ & & & \\
\hline
\end{tabular}


Empirical Results (cont.)

\begin{tabular}{|c|c|c|c|c|}
\hline & Rule of law & Government Size & Regulatory Efficiency & Open Markets \\
\hline $\begin{array}{l}\text { Government } \\
\text { Size }\end{array}$ & & $\begin{array}{c}0.351 \\
(0.179)^{\star *}\end{array}$ & & \\
\hline $\begin{array}{l}\text { Regulatory } \\
\text { Efficiency }\end{array}$ & & & $\begin{array}{c}0.402 \\
(0.086)^{\star \star *}\end{array}$ & \\
\hline $\begin{array}{l}\text { Open } \\
\text { Markets }\end{array}$ & & & & $\begin{array}{c}0.385 \\
(0.168)^{* *}\end{array}$ \\
\hline Constant & 0.338 & 2.901 & 1.365 & 2.229 \\
\hline & $(1.164)$ & $(2.827)$ & $(1.025)$ & $(1.467)$ \\
\hline Sargan test & 0.068 & 0.137 & 0.107 & 0.184 \\
\hline $\begin{array}{l}\text { Auto- } \\
\text { correlation } \\
\text { test }\end{array}$ & 0.259 & 0.162 & 0.248 & 0.266 \\
\hline
\end{tabular}

Values in the parentheses are Standard Errors. No Obs: 1.728. The P-values are reported for the Sargan and the auto-correlation tests. Significance levels: $0.01^{* \star}, 0.05^{\star *}, 0.1^{*}$.

The results in tables 3,4 and 5 with regard to the growth rate of sales, GDP and GDP per capita, resource intensity and operating costs, suggest that contrary to our expectations that FDI in all SEE economies will be mainly of the vertical, efficiency-seeking type, it is evident from the findings that neither the vertical, efficiency-seeking type nor the horizontal, marketseeking type of FDI dominates. Our findings coincide with the findings of Christie (2003) who suggested that in the SEE economies there is no clear distinction between efficiency and market seeking FDI type, and Kekic (2005), who suggested that the impact of market size, operating costs and natural resources were all statistical significant determinants on FDI in SEE economies.

\section{Conclusion}

This study originally presented the evolution of FDI in SEE briefly and compared the performance of the three countries, namely Bulgaria, Greece and Romania. The focus then turned to the role of institutions in attracting foreign investors in a country. In this context, the relevant literature was explored and the conclusions drawn in order to discuss the current status of institutions in SEE. Contrary to the main determinants of FDI location such as access to low-cost labor, large markets, and the availability of natural resources, which are diminishing in importance, other factors such as the overall stability of a country's economic and social institutions strongly determines its attractiveness as a FDI host country (Lucas 1990, Singh and Jun 1995).

Using firm and country-level data during 1996-2012, the significance and the effectiveness of a broad set of institutional and regulatory variables as factors that might have an effect FDI decision in the region and whether the contribution of regulatory and institutional factors driving FDI in the former transitional economies of Bulgaria and Romania are different than Greece was explored. They are found to be so. Overall, the results confirm the universal belief that the quality of institutions and regulations in a country are important factors in the decision of FDI.

The examination of the effect of the institutional and regulatory variables on FDI in all Southeastern economies confirmed their statistically significant influence on FDI decisions. In addition firm and country explanatory variables, not only had a statistically significant influence 
on the foreign investment decision, but they were statistically significant on the various regulatory and institutional variables.

Our analysis confirmed that quality of institutions and regulations have a significant positive effect on FDI. Besides the direct influence on the economic development of a SEE country, institutional and regulatory quality also affects the economy indirectly, through its impact on the level of FDI inflows. Other firm- and country- specific variables, such as Size, Age, R\&D intensity, Operating Costs and GDP per capita were also proved to have a statistically significant influence on FDI.

Greece, compared to Bulgaria and Romania, has not pursue any strong policies and institutions necessary for its integration in the world economy, thus it has not reaped any benefits from the increase in international capital movements, resulting in a small degree of participation in the international distribution of foreign investments in SEE. Greece faces inherent weaknesses for many years and eventually led to the crisis experienced for the seventh consecutive year. The crisis initiated a broad discussion for the need of redefining goals and policies with particular emphasis to be given to attempt to attract FDI as an essential ingredient for the restart of the country's economy and the creation of jobs.

In the past, there have been attempts to improve the business climate with the investment laws but these efforts are not enough. Greece needs consistent policies with clear frame and longterm strategic planning. The consolidation of the public sector with a radical restructuring of the structures and modes of operation is an essential precondition for any further action. The bureaucratic system must be eliminated in order to simplify the start-up procedures but also any activities concerning the relationships between the public and private sector in order to prevent any corruption phenomena. The prevalence of transparency has prominent role in ensuring the efficient operation of the state and therefore the confidence of foreign investors.

A long-term strategic planning is required for any macroeconomic and political stability. The successive changes in the tax regime for example constitute a serious obstacle to any interested foreign investor. FDI are long-term investments which are not easily reversible. Hence, any investor should be able to assess the revenue and the cost of its investment on long-term which implies that he knows in advance the legal and tax obligations.

Loose restrictions or tax incentives are not strong motives for foreign investors. Emphasis must be given to the reduction of bureaucratic procedures and a stable tax system, the development of trustworthy legal and anti-corruption system, a fair competition policy, and any other policies necessary to ensure that foreign investors in Greece will be treated in a fair and consistent way. In this respect, we must emphasize that it is very important for the future development of the Greek economy as an attractive FDI host country, that the government will pass all the necessary reforms on the business and regulatory environment.

The above conclusions are not wishful thinking. Policies, irrespective of the FDI, are the ones which ensure the healthy development of a country. However, they require a strong political will, in a country which for decades was structured upon perverse structures.

\section{References}

ACEMOGLU D., JOHNSON S., ROBINSON J. A. (2005), Institutions as a fundamental cause of long-run growth, in: AGHION P., DURLAUF S. N. (eds.), Handbook of Economic Growth, Volume 1A, North-Holland, Amsterdam, pp. 386-472.

ADDISON T., HESHMATI A. (2003), The New Global Determinants of FDI Flows to Developing Countries: The Importance of ICT and Democratization, UNU/WIDER Discussion Paper No. 2003/45, Helsinki. 
AKHTER S. H. (1993), Foreign direct investments in developing countries: The openness hypothesis and policy implications, The International Trade Journal 7 (6), 655-672.

AL NASSER O. M. (2007), The Determinants of the U.S. Foreign Direct Investment: Does the Region Matter? Global Economic Review 36 (1), 37-51.

ALTOMONTE C. (2000), Economic determinants and institutional frameworks: FDI in economies in transition, Transnational Corporations 9 (2), 75-106.

ALTOMONTE C., GUAGLIANO C. (2003), Comparative Study of FDI in Central and Eastern Europe and the Mediterranean, Economic Systems 27, 223-246.

APERGIS N., KATRAKILIDIS C. (1998), Does inflation uncertainty matter in foreign direct investment decisions? An empirical investigation for Portugal, Spain and Greece, RISEC International Review of Economics and Business 45 (4), 729-744.

ARELLANO M., BOND S. (1991), Some Tests of Specification for Panel Data: Monte Carlo Evidence and an Application to Employment Equations, Review of Economic Studies 58 (2), 277-297.

ASIEDU E. (2002), On the Determinants of Foreign Direct Investment to Developing Countries: Is Africa Different? World Development 30 (1), 107-119.

BAEK K., QIAN X. (2011), An Analysis on Political Risks and the Flow of Foreign Direct Investment in Developing and Industrialized Economies, Economics, Management and Financial Markets 6 (4), 60-91.

BALDWIN R. E., BRACONIER H., FORSLID R. (1999), Multinationals, endogenous growth and technological spillovers: theory and evidence, CEPR Discussion paper No. 2155.

BANIAK A., CUKROWSKI J., HERCZYNSKI J. (2005), On the Determinants of Foreign Direct Investment in Transition Economies, Problems of Economic Transition 48 (2), 6-28.

BARTHEL F., BUSSE M., NEUMAYER E. (2010), The Impact of double taxation treaties on foreign direct investment: Evidence from large dyadic panel data, Contemporary Economic Policy 28 (3), 366-377.

BÉNASSY-QUÉRÉ A., COUPET M., MAYER T. (2007), Institutional Determinants of foreign direct investment, The World Economy 30 (5), 764-782.

BENDE-NABENDE A., FORD J. L. (1998), FDI, policy adjustment and endogenous growth: Multiplier effects from a small dynamic model for Taiwan, 1959-1995, World Development 26 (7), 1315-1330.

BERGER A., BUSSE M., NUNNENKAMP P., ROY M. (2011), More Stringent BITs, Less Ambiguous Effects on FDI? Not a Bit! Economics Letters 112 (3), $270-272$.

BERGER A., BUSSE M., NUNNENKAMP P., ROY M. (2013), Do Trade and Investment Agreements Lead to More FDI? Accounting for Key Provisions Inside the Black Box, International Economics and Economic Policy 10 (2), 247-275.

BEVAN A. A., ESTRIN S. (2004), The determinants of foreign direct investment into European transition economies, Journal of Comparative Economics 32 (4), 775-787.

BILLINGTON N. (1999), The location of foreign direct investment: an empirical analysis, Applied Economics 31 (1), 65-76.

BITZENIS A., TSITOURAS A., VLACHOS V. A. (2009), Decisive FDI obstacles as an explanatory reason for limited FDI inflows in an EMU member state: The case of Greece, The Journal of Socio-Economics 38 (4), 691-704.

BLOMSTRÖM M., LIPSEY R. E., ZEJAN M. (1992), What explains developing country growth? NBER Working Paper No. 4132. Cambridge.

BLOMSTRÖM M., KOKKO A., ZEJAN M. (1994), Host Country Competition and Technology Transfer by multinationals, Weltwirtschaftliches Archiv, Review of World Economics 130 (3), 521-533.

BLONIGEN B. A. (2005), A review of the empirical literature on FDI determinants, Atlantic Economic Journal 33, 383-403.

BLUNDELL R., BOND S. (1998), Initial Conditions and Moment Restrictions in Dynamic Panel Data Models, Journal of Econometrics 87 (1), 115-143.

BORENSZTEIN E., DE GREGORIO J., LEE J-W. (1998), How does foreign direct investment affect economic growth? Journal of International Economics 45 (1), 115-135. 
An Analysis of the Economic Determinants and the Quality of the Institutional Framework as Factors to Attract Foreign Direct Investment in Southeastern Europe: the Case of Greece

BOSTON CONSULTING GROUP (2011), Hellas '20:20 Supporting investment in the Greek economy - a foreign investor perspective, The Boston Consulting Group (BCG).

BUCHANAN B. G., LE Q. V., RISHI M. (2012), Foreign direct investment and institutional quality: Some empirical evidence, International Review of Financial Analysis 21, 81-89.

BUSSE M., GROIZARD J. L. (2008), Foreign Direct Investment, Regulations and Growth, The World Economy 31 (7), 861-886.

BUSSE M., HEFEKER C. (2007), Political Risk, Institutions and Foreign Direct Investment, European Journal of Political Economy 23 (2), 397-415.

BUSSMANN M. (2010), Foreign direct investment and militarized international conflict, Journal of Peace Research 47 (2), 143-153.

CAMPOS N. F., KINOSHITA Y. (2003), Why does FDI go where it goes? New evidence from the transition economies, IMF Working Paper No. 03/228.

CAVES R. E. (1971), International Corporations: The Industrial Economics of Foreign Investment, Economica, 38 (149), 1-27.

CHOROMIDES C. (2003), Foreign Direct Investment and Greek Companies Internationalisation Strategies in the Balkans, PhD thesis, University of Edinburgh, Edinburgh.

CHRISTIE E. (2003), Foreign direct investment in Southeast Europe, WIIW Working Paper No. 24.

DAMIJAN J. P., KNELL M., MAJCEN B., ROJEC M. (2003), The Role of FDI, R\&D Accumulation and Trade in Transferring Technology to Transition Countries: Evidence from Firm Panel Data for Eight Transition Countries, Economic Systems 27, 2, 189-204.

DAUDE C., STEIN E. (2007), The Quality of Institutions and Foreign Direct Investment, Economics \& Politics 19 (3), 317-344.

DE GREGORIO J. (1992), Economic growth in Latin America, Journal of Development Economics 39 (1), 59-84.

DE MELLO L. R. (1999), Foreign direct investment-led growth: evidence from time series and panel data, Oxford Economic Papers 51 (1), 133-151.

DUNNING J. H. (1993), Multinational Enterprises and the Global Economy, AddisonWesley Publishing Company, Wokingham.

DUNNING J. H. (ed.) (2000), Regions, globalization, and the knowledge-based economy. Oxford University Press, Oxford.

DUTTA N., ROY S. (2009), What Attracts Foreign Direct Investment: A closer look, Economic Affairs, 29 (3), 81-86.

ESTRIN S., RICHET X., BRADA J. C. (eds.) (2000), Foreign Direct Investment in Central Eastern Europe: Case Studies of Firms in Transition, M. E. Sharpe, London. ESTRIN S., UVALIC M. (2013), Foreign direct investment into transition economies: Are the Balkans different? LEQS Paper No.64/2013, London.

FILIPPAIOS F., KOTTARIDI C. (2013), Complements or substitutes? New theoretical considerations and empirical evidence on the imports and FDI relationship in Central and Eastern European Countries, International Review of Applied Economics 27 (6), 766-797. FINDLAY R. (1978), Relative backwardness, direct foreign investment, and the transfer of technology: A simple dynamic model, The Quarterly Journal of Economics 92 (1), 1-16. FUNG K. C., IIZAKA H., PARKER S. (2002), Determinants of U.S. and Japanese Direct Investment in China, Journal of Comparative Economics 30 (3), 567-578.

GANI A. (2007), Governance and foreign direct investment links: Evidence from panel data estimations, Applied Economic Letters 14 (10), 753-756.

GETZ K. A., VOLKEMA R. J. (2001), Culture, perceived corruption and economics: A model of predictors and Outcomes, Business \& Society 40 (1), 7-30.

GLOBERMAN S., SHAPIRO D. (2002), Global foreign direct investment flows: the role of governance infrastructure, World Development 30 (11), 1899-1919.

GLOBERMAN S., SHAPIRO D. (2003), Governance Infrastructure and US Foreign Direct Investment, Journal of International Business Studies 34 (1), 19-39.

GLOBERMAN S., SHAPIRO D., TANG Y. (2006), Foreign Direct Investment in emerging and transition European countries, International Finance Review 6, 431-459. 
GROH A. P., WICH M. (2009), A Composite Measure to Determine a Host Country's Attractiveness for Foreign Direct Investment, IESE Business School Working Paper No 833, Barcelona.

HABIB M., ZURAWICKI L. (2002), Corruption and Foreign Direct Investment, Journal of International Business Studies 33 (2), 291-307.

HYMER S. (1960), On Multinational Corporations and Foreign Direct Investment, in:

Dunning J. H. (ed.), The Theory of Transnational Corporations, Routledge, London.

JOHNSON A. (2006), The effects of FDI Inflows on Host Country Economic Growth,

CESIS Electronic Working Paper Series No. 58.

KADITI E. A. (2013), Foreign Investments and Institutional Convergence in Southeastern Europe, International Economic Journal 27 (1), 109-126.

KEKIC L. (2005), Foreign direct investment in the Balkans: recent trends and prospects, Southeast European and Black Sea Studies 5 (2), 171-190. KHAN M. M., AKBAR M. I. (2013), The Impact of Political Risk on Foreign Direct Investment, International Journal of Economics and Finance 5 (8), 147-156.

KIM W. S., LYN E., ZYCHOWICZ E. (2003), Is the source of FDI important to emerging markets economies? Evidence from Japanese and US FDI, Multinational Finance Journal 7 (34), 107-130.

KIM D. D.-K., SEO J.-S. (2003), Does FDI inflow crowd out domestic investment in Korea? Journal of Economic Studies 30 (6), 605-622.

KINOSHITA Y., LU C.-H. (2006), On the role of absorptive capacity: FDI matters to growth, The William Davidson Institute Working Paper No. 845, Michigan.

KOBRIN S. J. (1976), The Environmental Determinants of Foreign Direct Manufacturing Investment: An Ex Post Empirical Analysis, Journal of International Business Studies 7 (2), 29 42.

LANKES H.-P., VENABLES A. J. (1996), Foreign direct investment in economic transition: the changing pattern of investment, Economics of Transition 4 (2), 331-347.

LIU X., BURRIDGE P., SINCLAIR P. J. N. (2002), Relationships between Economic Growth, Foreign Direct Investment and Trade: Evidence from China, Applied Economics 34 (11), 1433-1440.

LUCAS R. E. (1990), Why doesn't capital flow from rich to poor countries? The American Economic Review 80 (2), 92-96.

NAUDÉ W. A., KRUGELL W. F. (2007), Investigating geography and institutions as determinants of foreign direct investment in Africa using panel data, Applied Economics 39 (10), 1223-1233.

NIGH D. (1986), Political Events and the Foreign Direct Investment Decision: An Empirical Examination, Managerial and Decision Economics 7 (2), 99-106.

NONNENBERG M. J. B., MENDONÇA M. J. C. (2004), The Determinants of Foreign Direct Investment in Developing Countries, Encontro Nacional de Economia No. 061, Niteroi. Publishing OECD (2014), Greece at a Glance: Policies for a Sustainable Recovery, OECD PANTELIDIS P., NIKOLOPOULOS E. (2008), FDI attractiveness in Greece, International Advances in Economic Research 14 (1), 90-100.

PIKE A., RODRIGUEZ-POSE A., TOMANEY J. (2006), Local and regional development, Routledge, New York.

RAMCHARRAN H. (2000), Foreign Direct Investments in Central and Eastern Europe: An Analysis of Regulatory and Country Risk Factors, American Business Review 18 (2), 1-8. SHATZ H. J., VENABLES A. J. (2000), The Geography of International Investment, The World Bank Policy Research Working Paper No. 2338, Washington, DC.

SANCHEZ-ROBLES B. (1998), Infrastructure investment and growth: Some empirical evidence, Contemporary Economic Policy 16 (1), 98-109.

SCHOORS K., VAN DER TOL B. (2002), Foreign direct investment spillovers within and between sectors: Evidence from Hungarian data, Working Paper 2002/157, Ghent University, Ghent. 
An Analysis of the Economic Determinants and the Quality of the Institutional Framework as Factors to Attract Foreign Direct Investment in Southeastern Europe: the Case of Greece

SHAN J. (2002), A VAR Approach to the Economics of FDI in China, Applied Economics 34 (7), 885-893.

SINGH H., JUN K. W. (1995), Some new evidence on determinants of foreign direct investment in developing countries, The World Bank Policy Research Working Paper 1531, Washington, DC.

STERN N. (2003), Investment climate: lessons and change, The Egyptian Center for Economic Studies, Distinguished Lecture Series 19, Cairo.

TORRISI C. R., DELAUNAY C. J., KOCIA A., LUBIENIECKA M. (2008), FDI in Central Europe: Determinants and Policy Implications, Journal of International Finance and Economics 8 (4), 136-147.

VEREMIS T., DAIANU D. (eds.) (2001), Balkan Reconstruction, Routledge, London.

VITALIS V. (2002), Official Development assistance and Foreign Direct Investment: Improving the synergies, OECD, Paris.

VU T. B., NOY I. (2009), Sectoral analysis of foreign direct investment and growth in the developed countries, Journal of International Financial Markets, Institutions and Money 19 (2), $402-413$

WEI S.-J. (2000a), How taxing is corruption on international investors? The Review of Economics and Statistics $82(1), 1-11$.

WEI S.-J. (2000b), Local corruption and global capital flows, Brooking Papers on Economic Activity 2, 303-346.

WHEELER D., MODY A. (1992), International Investment Location Decisions: The case of U.S. Firms, Journal of International Economics 33 (1-2), 57-76.

WINDMEIJER F. (2005), A Finite Sample Correction for the Variance of Linear Efficient Two-step GMM Estimators, Journal of Econometrics 126 (1), 25-51.

ZHANG K. H. (2001), Does Foreign Direct Investment Promote Economic Growth? Evidence from East Asia and Latin America, Contemporary Economic Policy 19 (2), 175-185.

Initial submission: 07.04.2015

Revised submission: 03.06.2015

Final acceptance: 19.06 .2015

Correspondence: Faculty of Business and Economics, Metropolitan College, Sorou 74, Maroussi 151 25, Athens, Greece

E-mail: cchoromidis@metropolitan.edu.gr 
